\title{
PELAKSANAAN PIDANA DAN PEMBINAAN \\ NARAPIDANA TINDAK PIDANA NARKOTIKA (Studi terhadap Pembinaan Narapidana di Lembaga Pemasyarakatan Narkotika Klas IIA Yogyakarta)
}

\author{
Haryanto Dwiatmodjo \\ Fakultas Hukum Universitas Jenderal Soedirman Purwokerto \\ e-mail: haryanto_dwiatmodjo@yahoo.com
}

\begin{abstract}
ABSTRAK
Pelaksanaan pidana penjara yang merupakan bagian dari sistem peradilan pidana perlu segera dilakukan reorientasi mengingat sebagian besar sanksi pidana yang sekarang ada baik itu dalam Kitab Undang-Undang Hukum Pidana (KUHP) maupun dalam konsep Kitab Undang-Undang Hukum Acara Pidana Baru masih menggunakan bentuk sanksi berupa pidana penjara. Tujuan dijatuhkannya pidana penjara adalah untuk melindungi masyarakat maupun untuk memperbaiki hidup pelaku. Perkembangan lebih lanjut pidana penjara dijatuhkan agar si pelakunya dirasakan sebagai pembalasan. Pelaksanaan pidana penjara dengan sistem pemasyarakatan tidak hanya ditujukan untuk mengayomi masyarakat dari bahaya kejahatan melainkan juga untuk mengayomi dan memberi bekal hidup orang-orang yang tersesat karena melakukan tindak pidana. Namun kenyataannya tidak mudah mewujudkan tujuan mulia tersebut sebab praktek di lapangan masih banyak ditemui kendala dan hambatan diantaranya masih ditemukan berbagai bentuk kekerasan dan diskriminasi di Lembaga Pemasyarakatan.
\end{abstract}

Kata Kunci: pelaksanaan pidana, tindak pidana, penjara, pengaturan kriminalitas.

\begin{abstract}
Execution of imprisonement which are the part of criminal justice system needs to be reoriented considering that most criminal pinalties that now exists whether regulated inside the book of criminal law (KUHP) or inside the concept draft of the new criminal procedure law (RUU KUHAP) still using a form of sanctioned imprisonement. The imposition of imprisonment purpose is to protect the public as well as to improve the live of the offender. Further, the imposition of imprisonment purposed to give a pshycological effects of retaliation to the offender. Implementation imprisonment with correctional system, are not only intended to protect the public from the dangers of crime, but also giving enlightenment to other people so they can stay away from criminal act. But the fact is that it was not easy to achieve such lofty goal, because in practice there are so many obstacles and barriers encountered. There were still definetely various forms of violence and discriminantion in prison.
\end{abstract}

Keywords: criminal enforcement, crime, criminality regulation.

\section{PENDAHULUAN}

Sejalan dengan perkembangan jaman, hukum berkembang mengikuti setiap kebutuhan manusia. Hukum terus mengalami perubahan guna perbaikanperbaikan di segala segi kehidupan manusia demi terwujudnya tujuan nasional. Tak terkecuali di dalam sistem kepenjaraan di Indonesia. Sistem kepenjaraan telah mengalami perubahan karena dianggap tidak sesuai dengan sistem pemasyarakatan berdasarkan Pancasila dan Undang-Undang Dasar 1945 (yang selanjutnya disebut UUD 1945). Sistem kepenjaraan hanyalah mengutamakan pengenaan nestapa sehingga hak asasi narapidana tidak diindahkan.
Pada dasarnya semua hukum bertujuan untuk menciptakan suatu keadaan di dalam suatu pergaulan hidup masyarakat, baik di dalam lingkungan yang kecil maupun dalam lingkungan yang lebih besar, agar didalamnya terdapat suatu keserasian, suatu ketertiban, suatu kepastian hukum dan lain sebagainya (PAF Lamintang, 1997:16).

Untuk dapat menjamin adanya kepastian hukum, peraturan-peraturan yang terkait masalah pidana telah dituangkan dalam Kitab Undang-Undang Hukum Pidana (yang selanjutnya disebut KUHP) yang saat ini masih menjadi ketentuan pokok dari hukum pidana 
Indonesia. Mezger memberi definisi hukum pidana adalah aturan hukum yang mengikatkan pada suatu perbuatan yang memenuhi syarat-syarat tertentu suatu akibat berupa pidana (Sudarto, 1990:9).

Dalam sistem peradilan Indonesia, hukum pidana menjadi salah satu hal yang menjadi sorotan dan perhatian dari berbagai pihak terutama masyarakat. Salahsatu prinsip utama dalam dalam penyelengaraan peradilan pidana terpadu dengan diakuinya suatu asas equality before the law. Namun implementasi asas ini hanya berorientasi pada masyarakat sebagai salah satu pihak yang terlibat dalam perkara pidana baik sebagai saksi, pelaku maupun korban khususnya bagi yang dikenakan status tersangka, terdakwa maupun terpidana, padahal asas tersebut seharusnya juga berorientasi pada aparat penegak hukum khususnya hakim (Haryanto Dwiatmojo, 2012:1-126). Maka tak heran jika sebagian masyarakat menolak untuk menjadi saksi dalam mengungkap terjadinya tindak pidana sebab sebagai saksi bahkan korban sekalipun dalam kenyataannya ini kurang mendapat perhatian penegak hukum (Haryanto Dwiatmojo, 2011:187376). Namun kenyataan pengertian yang berkembang dalam masyarakat, pidana erat hubungannya dengan hukuman yang diberikan oleh pihak yang berwenang kepada seseorang yang bersalah dimana sifatnya menderitakan dan tidak menyenangkan.

Tahap pemidanaan atau penjatuhan pidana dalam perkara pidana kini menjadi hal yang penting untuk diperhatikan sebab terkait akan akhir daripada suatu proses perkara pidana yaitu keputusan hakim yang mengakibatkan seseorang dinyatakan bersalah atau tidak bersalah melanggar hukum untuk selanjutnya dikenakan pidana atau malah bebas dari hukum.

Pemidanaan sebagai suatu bagian dari mekanisme penegakan hukum pidana, diartikan juga sebagai suatu pemberian pidana, tidak lain merupakan suatu proses kebijakan yang mana direncanakan. Pemberian pidana benar-benar terwujud direncanakan melalui beberapa tahap, yaitu: tahap penetapan pidana oleh pembentuk undang-undang; tahap pemberian pidana oleh badan yang berwenang; tahap pelaksanaan pidana oleh instansi pelaksanaan yang berwenang (Muladi dan Barda Nawawi Arief, 1984:91).

Hakim sebagai tonggak penegakan hukum pidana dituntut untuk dapat memberikan putusan pemidanaan yang tepat, dalam mengenakan pidana pada setiap kasusnya tetap di dalam suatu koridor hukum pidana dengan KUHP sebagai ketentuan pokoknya hukum pidana materiil di Indonesia. Walaupun sebenarnya penyelesaian perkara pidana itu tidak harus melaui pengadilan sehingga penyelesaian perkara pidana dapat pula melaui jalur non litigasi sehingga model ini merupakan jalur alternatif di samping jalur utama litigasi (Agus Rahardjo, 2008:93).

Posisi sentral dari pidana (pemidanaan) itu pun bisa dilihat dari kekuasaan hakim yang amat luas dalam menjatuhkan pidana, dimana dalam melakukan penerapan pidana hakim memiliki kebebasan serta tidak terikat pada unsur lain. Menurut Muladi baik straf soort atau jenis dari pidananya, straf maat atau lamanya pidana dan straf modus atau bagaimana pelaksanaan suatu pidananya, hakim mempunyai keleluasaan untuk mendapatkan pidana yang tepat (Agus Rahardjo, 2008:56).

Secara filosofis pemasyarakatan adalah sistem pemidanaan yang sudah jauh bergerak meninggalkan filosofi retributive (tindakan pembalasan), deterrence (penjeraan) dan juga resosialiasi. Dengan kata lain pemidanaan tidak ditujukan untuk membuat derita sebagai bentuk pembalasan, tidak ditujukan untuk membuat jera dengan penderitaan, dan juga tidak mengasumsikan terpidana sebagai seseorang yang kurang sosialisasinya. Pemasyarakatan sejalan dengan filosofis reintegrasi sosial yang berasumsi kejahatan adalah konflik yang terjadi antara terpidana dengan masyarakat. Sehingga pemidanaan ditujukan untuk memulihkan konflik atau juga menyatukan kembali terpidana dengan masyarakatnya atau reintegrasi (Direktorat Jendral Pemasyarakatan, 2009:11).

Ketentuan Undang-Undang No. 12 Tahun 1995 tentang Pemasyarakatan, mengamanatkan bahwa suatu Lembaga Pemasyarakatan (yang selanjutnya disebut Lapas) yang merupakan institusi dari sub sistem peradilan pidana mempunyai fungsi strategis sebagai pelaksanaan pidana penjara sekaligus sebagai tempat bagi pembinaan narapidana. Fungsi Lapas yang demikian ini sesungguhnya sudah berbeda jauh serta lebih baik dibandingkan dengan fungsi penjara dengan jaman dahulu dengan dasar hukum Peraturan Penjara (Gestichten Reglement S.1917 No. 708).

Aturan Keputusan Menteri Kehakiman Republik Indonesia No. M.02.PK.04.10 Tahun 1990 mengenai Pola Pembinaan Narapidana atau Tahanan, Lapas di dalam sistem pemasyarakatan, selain berfungsi sebagai tempat pelaksanaan pidana penjara, juga mempunyai beberapa sasaran srategis di dalam hal pembangunan nasional. Tujuan tersebut antara lain menyatakan bahwa Lapas mempunyai fungsi ganda yakni sebagai suatu lembaga pendidikan dan lembaga pembangunan.

Pemidanaan adalah upaya terakhir dalam proses penegakan hukum pidana dan juga merupakan akhir atau puncak dari keseluruhan sistem upaya yang 
mana menggerakkan manusia melakukan tingkah laku tertentu seperti yang diharapkan masyarakat (Roeslan Saleh, 1983:1). Pemidanaan sebagai suatu proses penjatuhan pidana dan harus dilakukan dengan sebijak mungkin, perlu dipertimbangkan pidana yang bagaimana yang sesuai dengan kondisi si terdakwa. Harus diakui bahwa pidana itu tidak berakibat sama pada setiap orang, karena pidana merupakan suatu hal yang relatif (Niniek Suparmi, 2007:40).

Akhir-akhir ini sering mendengar kabar bahwa narapidana yang sedang menjalani pembinaan di suatu Lapas itu ternyata masih bisa mengendalikan kejahatannya dari tembok penjara. Akan tetapi di sisi yang lain dapat terlihat pula keberhasilan dari aparat kepolisian dalam menangani tindak pidana narkotika, antara lain yaitu sejumlah 26.498 perkara tindak pidana di bidang narkoba tahun 2012. Itu berarti terdapat peningkatan sebanyak 12,61 persen keberhasilan POLRI menangani kasus narkoba dari tahun sebelumnya, yaitu 23.531 perkara. Sedangkan barang bukti yang berhasil disita dan jika diuangkan dengan uang sebesar Rp920.710.292.657. Sedangkan pemakai pemula (generasi penerus) yang mana dapat diselamatkan mencapai 93.730.960 orang (Tempo, 2011, http://www.tempo.co/read/news/2011/12/31/ 063374607/Selama-2011-Kejahatan-Cyber-Narkobadan-Terorisme-Meningkat, diakses Selasa, tanggal 12 Februari 2013, Jam 21.00).

Keadaan demikian itu tentu saja menjadi menjadi keprihatinan bersama apakah ada yang salah dengan proses pelaksanaan pidana dan pembinaan narapidana di Lapas selama ini. Memang masalah penegakan hukum tidak hanya dilihat dari kaca mata undangundang saja, tetapi juga harus dilihat secara utuh dengan melibatkan semua unsur yang ada, seperti moral, perilaku dan budaya. Oleh karena itu, perlu orientasi dan cara pandang baru dalam penegakan hukum (Mahrus Ali, 2010:210-229).

\section{RUMUSAN MASALAH}

Penulisan ini dimaksudkan untuk mengetahui: Pelaksanaan Pidana dan pembinaan narapidana di Lapas Narkotika Klas IIA Yogyakarta; serta Kendala dalam pelaksanaan pembinaan narapidana di Lapas Narkotika Klas IIA Yogyakarta.

\section{METODE PENELITIAN}

Penelitian ini bersifat deskriptif dengan metode kualitatif dan pendekatan Yuridis Sosiologis (social legal approach) (Sanapiah F, 1990:22). Penelitian ini berusaha untuk dapat menggambarkan secara rinci fenomena sosial yang menjadi pokok permasalahan tanpa melakukan suatu hipotesa dan perhitungan cara statistik (Masri Singarimbun dan Sofian Effendi, 1987:4). Deskriptif bukan dalam arti sempit artinya dalam memberikan gambaran tentang fenomena yang ada dilakukan sesuai dengan metode ilmiah (I.S. Susanto, 1990:15). Pendekatan yuridis sosiologis dimaksudkan sebagai pemaparan dan pengkajian hubungan aspek hukum dengan aspek nonhukum dalam bekerjanya hukum di dalam kenyataan. Pada penelitian hukum sosiologis yang diteliti awalnya adalah data sekunder, untuk kemudian dilanjutkan dengan penelitian terhadap data primer di lapangan atau masyarakat (I.S. Susanto, 1990:52). Penelitian lapangan ini dilakukan dengan metode interview (Burhan Ashshofa, 1996:59). Hasil penelitian setelah diidentifikasi, dikonstruksikan, disusun dan dianalisis menggunakan metode kualitatif berdasarkan teori, asas-asas serta norma hukum yang berkaitan dengan pokok permasalahan yang diteliti (Lexy J. Moleong, 2004:103).

\section{PEMBAHASAN \\ Pelaksanaan Pidana dan Pembinaan Narapidana di Lembaga Pemasyarakatan Narkotika Klas IIA Yogyakarta}

Sebelum kita menuju kepada penjelasan tentang pelaksanaan sistem pemasyarakatan, kiranya perlu dijelaskan lagi bahwa konsepsi atas pemasyarakatan itu bukanlah semata-mata hanya merumuskan tujuan dari pidana penjara, melainkan merupakan suatu sistem pembinaan, suatu metodologi dalam bidang Treatment of Offenders yang multilateral oriented dengan pendekatan yang berpusat kepada potensipotensi yang ada baik itu ada pada individu yang bersangkutan, maupun yang ada di tengah-tengah masyarakat sebagai suatu keseluruhan atau community base treatment (Widiada Gunakarya, 1988:83).

Lapas Narkotika Klas IIA Yogyakarta dibentuk berdasarkan surat persetujuan Menteri Pendayagunaan Aparatur Negara No. B/86/M.PAN/1/2007 dan juga Keputusan Menteri Hukum HAM Republik Indonesia No. M.04-PR.07.03 Tahun 2007 tanggal 23 Februari 2007 tentang Pembentukan Lembaga Pemasyarakatan Narkotika Klas IIA Yogyakarta dan Tanjung Pinang. Lapas Narkotika Klas IIA Yogyakarta ini merupakan salah satu lembaga pemasyarakatan yang khusus menangani perkara-perkara terkait narkotika, yang mempunyai tugas pokok dan fungsi melaksanakan pembinaan Warga Binaan sistem pemasyarakatan agar menyadari kesalahan, memperbaiki diri, tidak mengulangi tindak pidana sehingga dapat diterima kembali secara wajar sebagai seorang warga yang 
baik dan bertanggungjawab. Lapas Narkotika Klas IIA Yogyakarta beralamat di jalan Kaliurang KM 17 Pakem, di Kabupaten Sleman. Bangunan Lapas ini dibangun di atas Tanah Sultan (Sultan Ground) seluas 30.170 meter persegi, dengan luas bangunan $8.579,46 \mathrm{~m}^{2}$.

Bangunan hunian Warga Binaan Pemasyarakatan atau yang kerap disebut paviliun terdiri dari Paviliun Anggrek, Paviliun Bougenville, Paviliun Cempaka, Paviliun Dahlia dan juga Paviliun Edelwise. Untuk sementara ini baru Paviliun Bougenville, Paviliun Cempaka, Paviliun Dahlia dan Paviliun Edelwise yang sudah dihuni oleh Warga Binaan Pemasyarakatan karena jumlah Warga Binaan Pemasyarakatan yang masih sedikit. Untuk Paviliun Edelwise dikhususkan untuk dihuni oleh Warga Binaan Pemasyarakatan berjenis kelamin wanita.

Lapas Narkotika Klas IIA Yogyakarta memiliki kapasitas standar sebanyak 474 orang dan kapasitas normal sebanyak 682 orang, pada saat ini dihuni narapidana yang seluruhnya merupakan terpidana yang mana melakukan tindak pidana penyalahgunaan narkotika dengan sanksi berupa pidana penjara.

Selengkapnya narapidana dengan sanksi pidana penjara berdasar jenis kelamin dapat dilihat pada tabel berikut:

Tabel 1. Jenis Kelamin Narapidana

\begin{tabular}{clcc}
\hline No. & \multicolumn{1}{c}{ Narapidana } & Frekuensi & Persentase \\
\hline 1. & Laki-laki & 199 & 97,07 \\
2. & Wanita & 6 & 2,93 \\
\hline & Jumlah & 205 & 100 \\
\hline
\end{tabular}

Sumber: Data primer diolah

Dari tabel di atas diketahui bahwa penghuni Lapas Narkotika Klas II A Yogyakarta paling banyak dihuni oleh narapidana narkotika berjenis kelamin laki-laki yakni 199 orang atau 97,07\% sedang sisanya 6 orang berjenis kelamin perempuan atau $2,93 \%$. Hal ini juga menunjukkan bahwa laki-laki paling banyak memiliki kencenderungan untuk melakukan tindak pidana di bidang narkotika dibandingkan dengan wanita.

Sedangkan jenis pekerjaan narapidana penghuni Lapas Narkotika Klas II A Yogyakarta dapat dilihat pada tabel berikut:

Tabel 2. Jenis Pekerjaan sebelum Menjadi Narapidana

\begin{tabular}{clcc}
\hline No. & \multicolumn{1}{c}{ Narapidana } & Frekuensi & Persentase \\
\hline 1. & Pelajar/Mahasiswa & 165 & 80,48 \\
2. & Karyawan/Buruh & 9 & 4,39 \\
3. & Wirausaha & 31 & 15,13 \\
\hline & Jumlah & 205 & 100 \\
\hline
\end{tabular}

Sumber: Data primer diolah
Dari tabel di atas dapat diketahui pelaku tindak pidana narkotika penghuni Lapas Narkotika Klas II A Yogyakarta paling banyak pelajar atau mahasiswa yakni ada 165 orang atau $80.48 \%$, berikutnya mereka yang memiliki pekerjaan wirausaha yakni 31 orang atau $15,13 \%$ sedang sisanya 9 orang atau hanya $4,39 \%$ memiliki pekerjaan karyawan atau buruh.

Sedangkan narapidana penghuni Lapas Narkotika Klas II A Yogyakarta berdasar kewarganegaraan dapat dilihat pada tabel berikut:

Tabel 3. Kewarganegaraan Narapidana

\begin{tabular}{clcc}
\hline No. & \multicolumn{1}{c}{ Narapidana } & Frekuensi & Persentase \\
\hline 1. & WNI & 201 & 98,04 \\
2. & Asing & 4 & 1,96 \\
\hline & Jumlah & 205 & 100 \\
\hline
\end{tabular}

Sumber: Data primer diolah

Dari tabel di atas diketahui bahwa narapidana penghuni Lapas Narkotika Klas II A Yogyakarta paling banyak yaitu berkewarganegaraan Indonesia yakni ada 201 orang atau 98,04\% sedang sisanya 4 orang atau $1,96 \%$ berkewarganegaraan asing. Hal ini menunjukkan dengan adanya penghuni di Lapas yang berkewarganegaraan asing mengindikasikan bahwa Yogyakarta potensi untuk dijadikan tujuan sindikat peredaran narkotika internasional. Pasal 1 Peraturan Pemerintah Republik Indonesia No. 31 Tahun 1999 tentang Pembinaan dan Pembimbingan Warga Binaan Pemasyarakatan merumuskan bahwa, pembinaan merupakan kegiatan yang meningkatkan kualitas ketaqwaan kepada Tuhan Yang Maha Esa, intelektual, sikap dan perilaku, profesional kesehatan jasmani dan juga rohani Narapidana dan Anak Didik Pemasyarakatan.

Dengan diterapkan sistem pemasyarakatan ini tidaklah saja merumuskan tujuan pidana penjara tetapi juga menerapkan sistem pembinaan narapidana yang mencakup pencegahan kejahatan dan juga untuk membentuk manusia yang baru yang nantinya bisa berguna juga dapatlah diterima oleh masyarakat. Pada Pasal 2 Undang-Undang No. 12 Tahun 1995 tentang Pemasyarakatan, merumuskan bahwasanya Sistem Pemasyarakatan ini diselenggarakan dalam rangka membentuk Warga Binaan Pemasyarakatan agar dapat menjadi manusia seutuhnya, menyadari kesalahan memperbaiki diri, dan tidak mengulangi tindak pidana sehingga dapat diterima kembali oleh lingkungan masyarakat, dapat aktif berperan dalam pembangunan dan dapat hidup secara warga yang baik dan bertangungjawab.

Dalam sistem pemasyarakatan terdapat proses pemasyarakatan yang mana diartikan sebagai suatu 
proses sejak seorang narapidana masuk ke Lapas sampai lepas kembali ke tengah-tengah masyarakat. Pemasyarakatan juga berfungsi untuk menyiapkan Warga Binaannya untuk dapat berinteraksi secara sosial di dalam masyarakat. Karena narapidana yang telah masuk ke dalam Lapas biasanya ia akan merasa terasingkan. Sehingga disini pembinaan dilakukan untuk mengatasi permasalahan itu. Hal tersebut diatur dalam Pasal 3 Undang-Undang No. 12 Tahun 1995 tentang Pemasyarakatan.

Pelaksanaan pembinaan terhadap para narapidana diatur di dalam Pasal 7 Peraturan Pemerintah No. 31 Tahun 1999 tentang Pembinaan dan Pembimbingan Warga Binaan Pemasyarakatan yakni merumuskan tentang pembinaan narapidana dilaksanakan melalui beberapa tahap pembinaan: tahap awal; tahap lanjutan; dan diakhiri dengan tahap akhir.

Surat Edaran Direktorat Jenderal Pemasyarakatan/ Bina Tuna Warga No. KP.10.13/3/31, Pemasyarakatan sebagai Proses, maka hendaknya disalurkan dalam tahap demi tahap guna mengindari kegagalan daripada akibat-akibat lain yang mana tidak diinginkan. Tahaptahapnya sebagai berikut:

Pertama, Hendaknya narapidana pada waktu akan datang ke Lapas dikenal dan diketahui dahulu apa kekurangan dan kelebihannya. Sebab-sebab sampai ia melakukan tindak pidana, dan lain-lain hal tentang dirinya. Dengan bahan tersebut dapat direncanakan, lalu dilakukan usaha pembinaan terhadapnya.

Kedua, Bilamana pembinaan dari narapidana dan hubungan dengan masyarakat telah berjalan selaras selama 1/3 dari masa pidana yang sebenarnya dan menurut pendapat Dewan Pembinaan Pemasyarakatan sudah dicapai kemajuan dalam proses maka dapat dipindah ke Lapas medium security. Di tempat baru ini narapidana diberi tanggungjawab lebih besar, lebihlebih dalam tanggungjawab terhadap masyarakat luar, bersamaan pula untuk rasa harga diri, untuk mana sehingga masyarakat timbul kepercayaannya dan merubah sikapnya terhadap narapidana.

Ketiga, Jika sudah dijalani kurang lebih separuh masa pidana yang sebenarnya dan menurut Dewan Pembinaan Pemasyarakatan proses pemasyarakatan telah mencapai kemajuan yang lebih, baik mengenai narapidana maupun unsur-unsur masyarakat, maka wadah perlu diperluas, dimulai dengan usaha asimilasi narapidana pada kehidupan masyarakat luar, seperti sekolah umum, beribadah, berolahraga dan lainnya. Segala masih dalam pengawasan dan bimbingan petugas pemasyarakatan.

Keempat, Akhirnya jika sudah menjalani 2/3 dari masa pidana yang sebenarnya, sedikitnya 9 bulan dapat dilepaskan pelepasan bersayarat, kalau proses berjalan dengan lancar dan baik. Pada tahap ini wadah proses pemasyarakatan berupa masyarakat luar yang luas. Hidup dan kehidupan narapidana dengan unsur dari masyarakat telah menjadi positif dan merupakan suatu kebutuhan, suatu integritas.

Sebagai suatu fungsi pemasyarakatan maka Lapas bukan saja sudah berubah dalam pola pembinaan yang dilakukan sekaligus juga sudah harus mengubah orientasinya dari lembaga konsumtif menjadi lembaga produktif. Pembinaan mental dan keterampilan yang diberikan sesuai dengan yang telah tercantum dalam Keputusan Menteri Kehakiman No. M.02.PK.04.10 Tahun 1990 tentang Pola Pembinaan Narapidana, terdiri dari Pembinaan Kepribadian dan Pembinaan Kemandirian, yaitu:

Pertama, Pembinaan Kepribadian: pembinaan kesadaran untuk beragama; pembinaan berbangsa dan bernegara; pembinaan kemampuan intelektual; pembinaan kesadaran terhadap hukum; pembinaan mengintegrasikan diri dengan masyarakat. Kedua, Pembinaan Kemandirian: juga keterampilan untuk mendukung akan usaha-usaha mandiri; keterampilan untuk mendukung usaha-usaha industri; keterampilan yang dikembangkan sesuai bakat masing-masing; mendukung usaha industri atau kegiatan pertanian.

Selain narapidana mendapatkan pendidikan dan diberikan keterampilan di dalam penjara, narapidana juga dapat mendapatkan pendidikan keagamaan guna memperbaiki mental dan jiwa mereka. Pembinaan dan juga bimbingan kemasyarakatan haruslah selalu ditingkatkan melalui pendekatan mental (agama, Pancasila, dan lain sebagainya) meliputi pemulihan harga diri sebagai pribadi maupun sebagai warga negara yang mana meyakini dirinya masih memiliki potensi produktif bagi pembangunan bangsa dan oleh karena itu mereka dididik (dilatih) juga untuk menguasai keterampilan tertentu guna dapat hidup mandiri dan berguna bagi pembangunan. Ini berarti bahwa pembinaan dan bimbingan yang diberikan mencakup bidang mental dan keterampilan.

Moch. Muhidin selaku Kasie Binadik atau Kepala Seksi Bimbingan Narapidana dan Anak Didik Lapas Narkotika Klas IIA Yogyakarta, menjelaskan bahwa di Lapas ini diperuntukan bagi narapidana kasus narkotika, disini merupakan tempat pembinaan bagi semua narapidana narkotika yang berada di Wilayah Daerah Istimewa Yogyakarta. Dibangunnya Lapas Narkotika Klas IIA Yogyakarta merupakan salah satu sikap keprihatinan dan kepedulian Pemerintah Daerah provinsi DIY dengan pihak terkait seperti Kementerian Hukum dan HAM, Departemen Agama 
dan masyarakat Yogyakarta atas maraknya tindak pidana narkotika (Wawancara Rabu, 16-01-2013).

Lebih lanjut lagi Moch. Muhidin menjelaskan mengenai pembinaan Warga Binaan melalui proses pemasyarakatan akan menempuh tahapan-tahapan. Tahapan-tahapan pembinaan itu dijabarkan sebagai berikut:

Pertama, yaitu Pembinaan pada Tahapan Awal, ketika pertamakali datang Warga Binaan akan di daftarkan di Bagian Registrasi, disana juga akan diperiksa kesehatannya. Disini para Warga Binaan akan dikenalkan dengan lingkungan barunya yaitu lembaga pemasyarakatan. Warga Binaan dijelaskan mengenai kenapa dirinya harus dibina di lembaga pemasyarakatan, dan agar menyadari kesalahannya, serta mengenai pembinaan akan kesadaran beragama; kesadaran berbangsa dan bernegara; kesadaran hukum dan kemampuan intelektual, hal tersebut diadakan di dalam program criminon Indonesia. Kemudian diamati dan diteliti mengenai bakat dan minat mereka untuk menentukan program pembinaan berikutnya. Tahap awal berlangsung paling lama 1 bulan. Tahap awal meliputi: 1. mapenaling atau masa pengamatan, pengenalan dan penelitian lingkungan; 2. perencanaan program pembinaan kepribadian dan kemandirian; 3 . pelaksanaan program kepribadian dan kemandirian; 4. penilaian pelaksanaan program pembinaan pada tahap awal.

Kedua, yaitu Pembinaan tahap lanjutan, setelah pembinaan tahap awal itu dijalani, Warga Binaan setelah selesai atau setelah 1/3-1/2 masa pidananya, dan telah lulus menjalani sidang Tim Pengamatan Pemasyarakatan (yang selanjutnya disebut TPP). Pembinaan tahap ini merupakan pembinaan lajutan daripada pembinaan kemandirian dan pembinaan kepribadian pada pembinaan di tahap awal. Warga Binaan dipekerjakan dalam kegiatan kerja di dalam bengkel kerja, serta akan tetap mendapatkan program pembinaan kepribadian. Setelah 1/2-2/3 masa pidana dan melalui sidang TPP lagi maka Warga Binaan akan melaksanakan program asimilasi. Dalam tahap lanjutan secara garis besar meliputi: 1. perencanaan program pembinaan lanjutan; 2. pelaksanaan program pembinaan lanjutan; 3. penilaian pelaksanaan program pembinaan lanjutan; 4 . perencanaan dan pelaksanaan program asimilasi.

Ketiga, Pembinaan tahap akhir, dalam tahap ini merupakan masa-masa akhir dari proses pembinaan. Tahap ini dilaksanakan setelah tahap lanjutan dan dijalani sampai masa pidananya berakhir. Dalam tahap ini Warga Binaan telah dirasakan cukup bekal untuk kembali menjalani kehidupannya dalam masyarakat.
Warga Binaan mengalami program integrasi agar dapat mengembalikan hubungan kemasyarakatan yang baik dengan masyarakat luar. Pembinaan tahap akhir meliputi: 1. perencanaan program integrasi; 2. pelaksanaan program integrasi; 3 . pengakhiran pelaksanaan pembinaan tahap akhir.

Dalam proses pembinaan dalam Lapas, Warga Binaan didampingi seorang Wali Pemasyarakatan. Wali adalah petugas pemasyarakatan yang melakukan pendampingan narapidana dan anak didik selama menjalani program pembinaan di Pemasyarakatan. Lapas Narkotika Klas IIA Yogyakarta memiliki 13 orang Wali Pemasyarakatan. Wali Pemasyarakatan melaksanakan tugas pendampingan baik saat dalam reinteraksi dengan sesama penghuni, atau petugas, keluarga maupun anggota pemasyarakatan lainnya. Wali Pemasyarakatan memilik kewajiban berupa: Pertama, Mencatat identitas, latar belakang tindak pidana, latar belakang kehidupan sosialnya, serta menggali potensi Warga Binaan untuk dikembangkan dan diselaraskan dengan program pembinaan. Kedua, Memperhatikan, mengamati, mencatat perkembangan pembinaan, perubahan perilaku yang dinilai positif, hubungan keluarga dan masyarakat, serta ketaatan terhadap tata tertib dari Lapas. Ketiga, Membuat laporan perkembangan pembinaan dan perubahan perilaku Warga Binaan untuk kepentingan sidang Tim pengamat Pemasyarakatan dalam menetapkan program pembinaan lanjutan.

Pelaksanaan pembinaan oleh Warga Binaan yang berada dalam Lapas Narkotika Klas IIA Yogyakarta, yang keseluruhannya merupakan terpidana tindak pidana akan penyalahgunaan narkotika sama dengan pembinaan pada umumnya seperti dalam ketentuan ketentuan Undang-Undang No. 12 tahun 1995 tentang Pemasyarakatan. Namun ada yang berbeda yaitu, pembinaan di Lapas narkotika lebih memperhatikan pada tingkat kesehatan Warga Binaannya, dimana para Warga Binaan yang mayoritas pengguna narkotika sangatlah rentan terhadap penyakit. Serta membangun mental mereka agar mau menjauhi narkotika.

Berikut petikan pendapat Warga Binaan setelah mengikuti pembinaan di Lapas Narkotika Klas IIA Yogyakarta:

Pertama, yaitu Misbah S., Warga Binaan yang berumur 22 tahun yang dikenakan pidana penjara selama 4 tahun dikarenakan melanggar ketentuan dalam Pasal 111, ayat 1 Undang-Undang No. 35 Tahun 2009 tentang Narkotika, berpendapat bahwa dirinya tidak melakukan tindak kejahatan karena dia tidak merugikan atau mencelakakan orang lain, dia hanyalah seorang korban dari narkotika karena 
telah menyalahgunakan narkotika. Setelah mengikuti pembinaan Misbah merasakan bahwa pembinaan sudah sangat baik dan juga sangat bermanfaat bagi dirinya. Pembinaan yang selama ini telah ia jalani sangatlah berguna sekali, dia dapat merenungkan kesalahan yang telah dilakukannya, perbuatannya itu telah merugikan dirinya dan keluarganya, dengan pembinaan ini dia bisa memperbaiki kelakuannya. Melalui pembinaan ia mendapatkan tambahan ilmu untuk bekal hidupnya nanti di dalam masyarakat. Beberapa program pembinaan yang telah dijalani antara lain program krominon, pembinaan religius dan program yang dinamakan VCT. Misbah juga berpendapat bahwasanya perlakuan petugas terhadap Warga Binaan sudah cukup baik, para petugas tetap menghargai para Warga Binaan. Setelah bebas nanti Misbah tidak memiliki rencana khusus, dia hanya ingin mengikuti arus yang penting dia berbuat tidak merugikan orang lain.

Kedua, Riszky Amendola, Warga Binaan yang berumur 24 tahun dan mengalami masa pidana selama 4 tahun di Lapas Narkotika karena telah melanggar ketentuan Pasal 111 ayat 1 Undang-Undang No. 35 Tahun 2009 tentang Narkotika, Riszky berpendapat saya tidak melakukan kejahatan karena saya hanya korban dari narkotika karena telah menggunakan narkotika secara melawan hukum, beliau sangatlah menyesal karena telah melakukan kesalahan tersebut karena jauh dari keluarga dan teman-teman. Reszky berpendapat bahwa pembinaan yang telah dia jalani sudah sangat sesuai dengan prinsip pengayoman karena disini beliau telah dibuat menjadi manusia yang mana bisa menghargai sesuatu hal dari hal yang kecil sampai yang besar. Dengan pembinaan yang telah dijalaninya selama ini Reszky mengungkapkan bahwa pembinaan sangatlah berguna sekali karena apa yang diajarkan disini pasti akan dibawa sampai saya keluar. Beberapa program pembinaan yang telah dijalaninya antara lain pembinaan rohani keagamaan seperti: sholat berjamaah, pengajian, iqra', pelatihan bahasa Mandarin. Dengan pembinaan dia merasa lebih tenang dalam menjalani sisa hukuman sampai dia bebas. Mengenai perlakuan dari petugas Lapas, Reszky berpendapat bahwasanya perlakuan petugas cukup baik, dimana jika kita sopan pada petugas maka petugas juga akan baik kepada kita. Reski juga mengutarakan keinginannya jika telah bebas nanti, dia ingin mencari pekerjaan karena ingin membahagiakan kedua orangtuanya.

Untuk menjaga dan jugas meningkatkan kualitas kesehatan Warga Binaan yang telah menyalahgunakan narkotika, Lapas narkotika ini menjalin kerjasama dengan Rumas Sakit Grasia, Rumah Sakit Sardjito dan LSM yang konsen di bidang kesehatan khususnya narkotika. Kegiatan-kegiatan tersebut adalah:

Pertama, Setiap Warga Binaan Pemasyarakatan baru diadakan pemeriksaan kesehatan.

Kedua, Setiap hari para Warga Binaan diadakan pemeriksaan kesehatan.

Ketiga, Melaksanakan program VCT (Voluntery Conseling Test) yaitu suatu program konsultasi test penyakit HIV/AIDS yang memberikan pengetahuan mengenai seluruh hal yang berhubungan dengan penyakit HIV/AIDS, dimana pelaku penyalahgunaan narkotika sangat rentan terhadap penyakit ini. Disini Warga Binaan didampingi oleh seorang Konselor VCT yang mana akan selalu memberikan perhatian, pendampingan dan penyiapan mental baik pada saat sebelum test, pada saat test dan pasca test mengenai test apakah Warga Binaan tesebut negatif atau positif mengidap HIV/AIDS.

Keempat, yaitu melaksanakan program Teurapic Community (TC) yaitu program atau sarana untuk curhat, berbagi cerita, pengalaman dan pengetahuan dari setiap Warga Binaan di dalam kelompok Teurapic Community tersebut yang berguna bagi para Warga Binaan lain dan lingkungan pemasyarakatan, agar tercipta satu kerukunan dan kesadaran.

Kelima, Melaksanakan program yang dinamakan PE (Peer Education) yaitu program yang mendidik Warga Binaan yang ditunjuk untuk menjadi intruskstur tentang masalah narkotika dan penyakit-penyakit yang berhubungan dengan narkotika khususnya HIV/AIDS, yang nantinya akan menyalurkan pengetahuannya kepada Warga Binaan yang lain.

keenam, Yaitu melaksanakan program Komuniksi Informasi dan Edukasi atau KIE.

Ketujuh, Melaksanakan Program KDS (Kelompok Dukungan Sebaya) yaitu program yang bertujuan untuk meningkatkan solidaritas atau dukungan dari setiap Warga Binaan, agar setiap Warga Binaan timbul rasa percaya diri dan tidak merasa dikucilkan.

Kedelapan, Melaksanakan Program NA (Narkotic Anonimus) yaitu program penyuluhan pemberian pengetahuan tentang segala hal yang berhubungan dengan narkotika.

Kesembilan, yaitu mengadakan Konseling Pribadi, dimana setiap Warga Binaan dapat berkonsultasi mengenai masalah-masalah atau unek-unek yang sedang dihadapi. Konseling ini bersifat insidental, jika ada Warga Binaan memerlukan konseling maka dipersilahkan untuk berhubungan dengan konselor. Disini konselor harus menjadi pendengar aktif dan memberikan pengertian-pengertian, karena konselor 
bukan pemecah masalah, yang bisa menyelesaikan masalah adalah Warga Binaan itu sendiri.

Dalam hal mendapatkan beberapa buku bacaan, Warga Binaan disediakan suatu ruangan perpustakaan yang nyaman dengan koleksi buku-buku yang bagus guna menunjang pembinaan. Lapas dalam hal ini bekerjasama dengan Dinas Pendidikan setempat, dalam penyedian bahan bacaan, jadi setiap bulan Dinas Pendidikan memberikan bantuan buku-buku bacaan bagi Warga Binaan.

Lapas ini juga menerapkan kebijakan bahwasanya di dalam Lapas itu bebas dari peredaran uang dan handphone, baik untuk petugas maupun bagi Warga Binaan. Disini peredaran uang sangatlah dilarang untuk mengantisipasi penyalahgunaan uang tersebut agar tidak disalahgunakan untuk kegiatan berjudi. Lapas menyediakan nomer rekening untuk setiap keluarga ataupun kerabat Warga Binaan jika ingin mengirim uang, dan juga apabila ada Warga Binaan yang membutuhkan uang maka harus menghubungi bagian register dan mencairkan uang tersebut dengan voucher, voucher tersebut berlaku hanya untuk hari itu juga, hal ini juga digunakan untuk mengantisipasi perjudian di dalam Lapas. Untuk kebijakan Lapas bebas dari handphone, Lapas menyediakan wartel untuk alat komunikasi Warga Binaan.

\section{Hambatan di dalam Pelaksanaan Pembinaan di Lembaga Pemasyarakatan Narkotika Klas IIA Yogyakarta}

Setiap Lapas Narkotika pasti akan mengahadapi suatu hambatan atau kendala yang dapat menggangu berjalannya proses pembinaan yang dilaksanakan di dalam Lapas tersebut. Demikian halnya juga dengan Lapas Narkotika Klas IIA Yogyakarta ini mempunyai hambatan atau kendala, baik dari dalam maupun dari luar Lapas, pada waktu melaksanakan proses pembinaannya terhadap narapidana.

Dalam melaksanakan suatu pembinaan, tidaklah terlepas dari hambatan-hambatan yang ada. Disini mencoba untuk mengklasifikasikan hambatan dalam proses pembinaan yang didapat dari wawancara, hambatan tersebut antara lain yakni:

Pertama, Kurangnya Kualitas dan juga Kuantitas Petugas dari Lapas Narkotika Klas II A Yogyakarta. Marasidin Siregar (Wawancara Senin, 14 Januari 2013) selaku Kalapas menyatakan Jumlah petugas pada umumnya sudah memenuhi untuk melakukan pembinaan, namun untuk ahli tenaga medis masih sangatlah kurang. Lapas narkotika hanya memilik 2 orang dokter dan juga 2 orang perawat, sehingga masih sangat kurang dibandingkan dengan jumlah narapidana yang mencapai 200 orang lebih. Tenaga medis sangat dibutuhkan dalam proses pembinaan di Lapas Narkotika karena para narapidana sangat rentan terhadap penyakit. Untunglah saja, Lapas ini bekerjasama dengan RS. Grasia dan juga RS. Sardjito dalam bidang medis sehingga masih dapat mengantisipasi bila terjadi masalah-masalah yang berhubungan dengan kesehatan.

Kedua, Faktor Sarana dan Prasarana. Kurangnya sarana dan juga prasarana dalam bidang olahraga karena hanya terdapat dua lapangan yang cukup kecil, yang satu digunakan untuk kegiatan upacara dan bola voly, dan yang mana satunya dipergunakan untuk kegiatan olahraga badminton dan futsal. Menurut Rudi Purnama yang merupakan salah satu Warga Binaan mengungkapkan, "Iya mas kalo ada yang ingin main futsal itu harus tunggu yang main badminton selesai dulu, jadi gantian-gantian..." (Wawancara Senin, 14 Januari 2013, dengan Bimaswat Lapas Narkotika Klas IIA Yogyakarta). Serta kurangnya lahan untuk program kemandirian dimana hanya disediakan bengkel kerja, lahan perkebunan, dan perikanan yang kurang memadai, sebab masih banyak program kemandirian yang akan direncanakan untuk masa mendatang namun belum memiliki cukup lahan untuk terealisasikannya program tersebut seperti, bengkel motor dan gypsum. Seperti yang diungkapkan oleh Syawaldi selaku Kepala Seksi Kegiatan Kerja (Wawancara Jumat, 18 Januari 2013 di Bengkel Kerja Lapas Narkotika Klas IIA Yogyakarta), yaitu rencananya akan ada kegiatan kerja baru, ada bengkel motor dan pembuatan gypsum, alat-alatnya sudah ada tapi belum tau tempatnya dimana mas, bengkel kerjanya tidak begitu luas.

Ketiga, Faktor dari pihak Pemerintah. Pembinaan narapidana tidak hanya tanggungjawab dari Lapas saja melainkan juga tanggungjawab bersama antara Lapas, pemerintah, dan juga masyarakat. Disinilah peran pemerintah sudah cukup baik namun masih kurang dalam hal belum dibuatnya suatu pengaturan khusus tentang Lapas narkotika, sehingga pembinaan di Lapas Narkotika masih bertumpu pada UndangUndang No. 12 Tahun 1995 tentang Pemasyarakatan, dimana undang-undang ini masih bersifat umum.

Keempat, Faktor dari para Narapidana. Menurut Marasidin Siregar selaku Kalapas, dalam pelaksanaan program pembinaan faktor penghambat itu juga bisa berasal dari narapidananya. Tidak sedikit narapidana yang kurang sadar terhadap pentingnya pembinaan ini dikarenakan sifat mereka yang cenderung malas. Kebanyakan dari mereka itu berasal dari kalangan orang-orang yang mampu, mereka seakan bermalas- 
malasan dan tidak begitu tertarik dengan program pembinaan (Wawancara Jumat, 18 Januari 2013 di Bengkel Kerja Lapas Narkotika Klas IIA Yogyakarta). Disamping itu juga kadang-kadang ada Warga Binaan yang berselisih dengan Warga Binaan lain sehingga menimbulkan keributan. Namun hal tersebut dapat diatasi dengan reward and punishment. Narapidana yang memiliki kelakuan baik akan mendapatkan penghargaan yaitu seperti, mendapatkan pembebasan bersyarat dan cuti menjelang bebas. Untuk narapidana yang melanggar tata tertib itu akan mendapatkan punishment.

Kelima, Faktor Masyarakat. Para masyarakat itu seharusnya juga ikut berpartisipasi dalam pelaksanaan pembinaan karena tujuan utama dalam pembinaan ini adalah narapidana ini bisalah diterima lagi oleh masyarakat. Namun harapan itu tidak selalu sesuai dengan kenyataan, hanya sedikit saja masyarakat yang ingin berpartisipasi selebihnya mereka hanya bersikap acuh terhadap narapidana. Padahal yang dibutuhkan oleh narapidana ini adalah perhatian dari sekeliling daerah lingkungannya. Menurut Marasidin Siregar selaku Kalapas Narkotika Klas IIA Yogyakarta: Ada beberapa kelompok kecil masyarakat yang bersedia membantu program pembinaan, namun kebanyakan masyarakat ini masih acuh (Wawancara hari Senin, pada tanggal 14 Januari 2013 dengan Kepala Lapas Narkotika Klas IIA Yogyakarta).

Keenam, Faktor Dana. Faktor penghambat ini akan terjadi di hampir semua Lapas di Indonesia, memang untuk membuat suatu program pembinaan bagi narapidana itu tidaklah membutuhkan biaya yang sedikit, ketiadaan suatu anggaran biaya akan sangat mempengaruhi jalannya proses pembinaan narapidana karena hampir semua hambatan di dalam keseluruhan proses pembinaan itu terbentur dalam hal anggaran dana atau biaya. Marasidin Siregar, selaku Kalapas mengungkapkan, pada prinsipnya setiap program pastinya memerlukan dana. Tidak terlepas dalam pelaksanan pembinaan ini yang juga memerlukan dana. Dengan dana yang terbatas membuat Lapas ini mencari jejaring untuk mendapatkan sponsor. Tidak banyak yang bisa membantu, sehingga membuat petugas harus ekstra efisien dalam menggunakan dana (Wawancara Senin, 14 Januari 2013 dengan Kepala Lapas Narkotika Klas IIA Yogyakarta).

\section{PENUTUP}

\section{Kesimpulan}

Pertama, Pembinaan yang dilakukan di Lapas Narkotika Klas IIA Yogyakarta kurang maksimal, namun penanganannya telah sesuai dengan Undang-
Undang No. 12 Tahun 1995 tentang Pemasyarakatan, yang mana pelaksanaannya diatur dengan Peraturan Pemerintah No. 31 Tahun 1999 tentang Pembinaan dan Pembimbingan Warga Binaan Pemasyarakatan. Lapas Narkotika Klas IIA Yogyakarta juga telah memenuhi hak-hak dari para narapidana. Sehingga tujuan Sistem Pemasyarakatan dapat dicapai yaitu membentuk Warga Binaan Pemasyarakatan agar jadi manusia yang seutuhnya, menyadari kesalahannya, memperbaiki diri, dan juga tidak mengulangi lagi tindak pidana sehingga bisa diterima kembali oleh lingkungan masyarakat, berperan aktif dalam hal pembangunan serta hidup secara wajar sebagai warga yang baik dan bertanggungjawab.

Kedua, Dalam proses pelaksanaan pembinaan narapidana terdapat beberapa hambatan, antara lain: 1. Jumlah petugas medis yang dirasa masih kurang, karena masalah rehabilitasi kesehatan merupakan masalah yang harus diterapkan kepada narapidana narkotika, dan narapidana narkotika rentan terhadap penyakit; 2 . Partisipasi narapidana dalam pembinaan rendah, diketahui berapa narapidana malas-malasan dan belum menyadari pentingnya pembinaan bagi mereka; 3. Beberapa program pembinaan, sudah siap untuk dapat dijalankan namun masih terkendala ruangan yang terbatas, kegiatan kerja yang sudah baik terhambat oleh keterbatasan lahan, terutama lahan perkebunan dan perikanan; 4. Minimnya anggaran biaya kegiatan pembinaan untuk seluruh kegiatan pembinaan yang sudah diprogramkan yang dalam programnya Lapas Narkotika ini haruslah menjalin kerjasama dengan para pihak-pihak lain agar dapat menjalankan pembinaan dengan baik, dana yang ada harus digunakan efisien dan efektif agar pembinaan tetap berjalan dengan baik; 5 . Stigma masyarakat terhadap narapidana itu masih sangat buruk terlihat hanya sedikit saja masyarakat yang ikut membantu dalam program pembinaan, kebanyakan masyarakat acuh tak acuh dalam proses ini, padahal partisipasi masyarakat sangatlah diperlukan dalam program pembinaan karena setelah bebas perhatian masyarakat kepada para mantan narapidana tetap diperlukan agar mereka tidak terasing.

\section{Rekomendasi}

Pertama, Lebih memaksimalkan lagi pembinaan di Lapas Narkotika Klas IIA Yogyakarta. Kedua, Menambah jumlah petugas medis di Lapas Narkotika Klas IIA Yogyakarta. Ketiga, Dapat meningkatkan partisipasi narapidana dalam hal pembinaan. Keempat, Menambah ruangan atau lahan agar program-program pembinaan dapat berjalan maksimal. 


\section{DAFTAR PUSTAKA}

\section{Buku:}

Ali, Mahrus, 2010, Sistem Peradilan Pidana Progresif: Alternatif dalam Penegakan Hukum Pidana, Jurnal Hukum No. 2 Vol. 14 April 2007.

Ashshofaa, Burhan, 1996, Metode Penelitian Hukum, Jakarta: Rineka Cipta.

Direktorat Jendral Pemasyarakatan, 2004, 40 Tahun Pemasyarakatan: Mengukir Citra Profesionalisme. Jakarta: Direktorat Jendral Pemasyarakatan. , 2009, Cetak Biru Pembaharuan Pelaksanaan Sistem Pemasyarakatan, Jakarta: Direktorat Jendral Pemasyarakatan.

Dirjosisworo, Soedjono, 1987, Hukum Narkotika Indonesia, Bandung: Alumni.

Dwiatmodjo, Haryanto, 2012, Penjatuhan Pidana Bersyarat dalam Kasus Pencurian Kakao, Jurnal Yudisial Vol. V No. 1 April 2012. , 2011, Pelaksanaan Perlindungan Hukum terhadap Anak yang Menjadi Korban Tindak Pidana di Wilayah Hukum Pengadilan Negeri Banyumas, Jurnal Dinamika Hukum Vol. 11 No. 2 Mei 2011.

Faisal, Sanapiah, 1990, Penelitian Kualitatif, Dasardasar dan Aplikasi, Malang: YA3 Malang.

Gunakarya, Widiada, 1988, Sejarah dan Konsep Pemasyarakatan, Bandung: Amrico.

Gunakarya, Widiada, 1988, Sejarah dan Konsepsi Pemasyarakatan, Bandung: Amrico.

Lamintang, PAF, 1984, Hukum Penitensier Indonesia, Bandung: Armico. , 1997, Dasar-dasar Hukum Pidana Indonesia, Bandung: Citra Aditya Bakti.

Moleong, Lexy J., 2004, Metode Penelitian Kualitatif, Bandung: Remaja Rosdakarya.

Muladi dan Barda Nawawi Arief, 1984, Teori-teori dan Kebijakan Pidana, Bandung: Alumni.

Priyatno, Dwidja, 2006, Sistem Pelaksanaan Pidana Penjara di Indonesia, Bandung: Refika Aditama.

Rahardjo, Agus, 2008, Mediasi sebagai Basis dalam Penyelesaian Perkara Pidana, Jurnal Mimbar Hukum, Fakultas Hukum UGM Yogyakarta. Vol. 20 Tahun 2008.
Saleh, Roeslan, 1983, Perubahan Pidana dan Pertanggungjawaban Pidana, Jakarta: Aksara Baru.

Singarimbun, Masri dan Sofian Effendi, 1987, Metode Penelitian Survei, Jakarta: LP3ES.

Soekanto, Soerjono dan Sri Mamuji, 1985, Penelitian Hukum Normatif, Jakarta: Rajawali.

Soemitro, Ronny Hanitidjo, 1990, Metodologi Penelitian dan Jurumetri, Jakarta: Ghalia Indonesia.

Sudarto, 1981, Kapita Selekta Hukum Pidana, Bandung: Alumni. , 1990, Hukum Pidana I, Cetakan ke II, Semarang: Yayasan Sudarto, Fakultas Hukum UNDIP.

Suparni, Niniek, 2007, Eksistensi Pidana Denda dalam Sistem Pidana Pemidanaan, Jakarta: Sinar Grafik.

Susanto I.S., 1990, Kriminologi, Semarang: Fakultas Hukum UNDIP.

\section{Peraturan Perundang-undangan:}

Undang-Undang No. 12 Tahun 1995 tentang Pemasyarakatan.

Undang-Undang No. 35 Tahun 2009 tentang Narkotika.

Peraturan Pemerintah No. 31 Tahun 1999 tentang Pembinaan dan Pembimbingan Warga Binaan Pemasyarakatan.

Keputusan Menteri Kehakiman Republik Indonesia No. 02-PK.04.10 Tahun 1990 tentang Pola Pembinaan Narapidana atau Tahanan.

\section{Website:}

http://nasional.news.viva.co.id/news/read/ 370658-7-napi-pengendali-narkoba-dari-lpnusakambangan.

Tempo, 2011, Selama 2011 Kejahatan Cyber, Narkotika dan Terorisme Meningkat. http:// www.tempo.co/read/news/2011/12/31/063374607/ Selama-2011-Kejahatan-Cyber-Narkoba-danTerorisme-Meningkat. 